\title{
ANALISIS KELAYAKAN DAN RISIKO USAHATANI KENTANG DI DESA KUTABAWA KECAMATAN KARANGREJA KABUPATEN PURBALINGGA
}

\author{
Yusuf Enril Fathurrohman dan Rahmi Hayati Putri \\ Program Studi Agribisnis, Fakultas Pertanian, Universitas Muhammadiyah Purwokerto \\ Email: yusuf.enril@gmail.com
}

\section{Diserahkan: 8 November 2020 Diterima: 7 Desember 2020}

\begin{abstract}
This study aims to determine the feasibility of potatoes farming in Kutabawa Village, Karangeja District, Purbalingga Regency and the farming risks such as production, price and income. The method used in this research is descriptive analysis method with 30 respondents who were taken through the survey method. The results showed that the feasibility study was obtained by an $R / C$ ratio of 2.33 or $>1$ which indicated that potatoes farming in Kutabawa Village, Karangreja District, Purbalingga Regency was feasible with an average income of IDR 50,633,333 and a total cost of IDR 21,744,673. In terms of production and income, it has a high risk because it has a variation coefficient of more than 0.5 (0.7945 for production and 1.00895177 for income) and also a lower limit of production of $-4123 \mathrm{~kg}$ and a lower limit of income of - Rp.29,405. 870 where it is less than 0 . Whereas seen from the price aspect it has a coefficient of variation less than 0.5 $(0.206965<0.5)$ and also a lower limit of production of IDR 4253.71 where the farm will always profit or break even with an increase in price of Rp. IDR 4253.71.
\end{abstract}

Keywords : Potatoes Farming, Feasibility Study, Risk Analysis

\section{PENDAHULUAN}

Kabupaten Purbalingga merupakan Kabupaten yang menempati urutan ke-10 sebagai area produksi kentang di Jawa Tengah dengan luas lahan mencapai 114 ha, produksi 20.535 dan produktivitas $180.33 \mathrm{kw} / \mathrm{ha}$ pada tahun 2015-2016 (Badan Pusat Statistik, 2018). Selain itu komoditas kentang di Kabupaten Purbalingga merupakan jenis sayuran yang paling diminati pada tahun 2017 (BPS Kabupaten Purbalingga, 2018). Lebih lanjut menurut data BPS (2016), Kecamatan Karangreja merupakan satu-satunya daerah produksi kentang di Kabupaten Purbalingga diantara 22 kecamatan yang ada. Hal ini memang sesuai dengan topografi Kecamatan Karangreja yang berada di daerah pegunungan tepatnya di kaki Gunung Slamet sehingga sesuai dengan berbagai jenis tanaman sayuran.
Produksi kentang pada tahun 2015 di Kecamatan Karangreja merupakan jumlah panen terbesar dengan jumlah panen sebanyak $3.854,78$ ton yang diikuti komoditas kubis, bawang daun dan wortel (BPS, 2016) Meski menjadi komoditas dengan produksi terbesar dibandingkan komoditas lainnya di Kabupaten Purbalingga namun pada kurun 5 tahun (2013 hingga 2017) terjadi penurunan pada luas panen, produksi dan produktivitas. Pada tahun 2013 produktivitas kentang sebesar 16,11 ton/ha dan menurun hingga 5,57 ton/ha pada tahun 2017. Hal ini sangat dipengaruhi dari penurunan luas lahan dan juga produksi kentang itu sendiri.

Diantara 5 Desa/Kelurahan yang ada di Kecamatan Karangreja, Desa Kutabawa merupakan salah satu desa yang sesuai untuk ditanami kentang dikarenakan memiliki 
topografi $630-1.300 \mathrm{mdpl}$ dengan suhu $20^{\circ}$ Celcius dan juga tanah yang dimiliki adalah tanah Andosol (Safitri, 2015). Usahatani kentang di Desa Kutabawa merupakan sumber pendapatan dan penyerapan tenaga kerja sebagian besar masyarakat Desa. Permasalahan produksi kentang secara umum yang dialami di Kecamatan Karangreja khususnya Desa Kutabawa biasanya disebabkan oleh berbagai faktor diantaranya iklim, biaya produksi, lahan prtanian, faktor produksi, perubahan harga, dan lain sebagainya. Menurut Kuntjoro (2000) fluktuasi produksi dan produktivitas kentang biasa disebabkan oleh beberapa kendala diantaranya rendahnya kualitas dan kuantitas bibit kentang khususnya pada teknik budidaya yang masih konvensional. Penurunan produksi dan produktivitas tersebut mengindikasikan bahwa usahatani kentang memiliki masalah dan risiko di dalamnya.

Berdasarkan uraian tersebut diketahui bahwa risiko berpengaruh terhadap kegiatan usahatani khususnya pada operasional seperti produksi, harga dan pendapatan. Oleh karenanya maka diperlukan penelitian mengenai Analisis Kelayakan dan Risiko Usahatani Kentang di Desa Kutabawa Kecamatan Karangreja Kabupaten Purbalingga.

\section{METODE PENELITIAN}

\section{Metode Penelitian}

Metode penelitian yang digunakan dalam penelitian ini adalah deskriptif analisis yakni dengan mengumpulkan data-data sesuai dengan yang sebenarnya kemudian data tersebut disusun, diolah dan dianalisis untuk dapat memberikan gambaran mengenai masalah yang ada (Sugiyono, 2008).

\section{Populasi dan Sampel}

Pengambilan data pada penelitian ini menggunakan metode survey (Sugiyono, 2009). Adapun teknik pengambilan sample dalam penelitian ini menggunakan Purposive Sampling yaitu teknik pengambilan sampel dengan pertimbangan tertentu (Sugiyono, 2016) dengan jumlah sampel 20\% dari populasi (Arikunto, 1998). Populasi petani kentang Di Desa Kutabawa Kecamatan Karangreja Kabupaten Purbalingga sebanyak 150 petani sehingga diambil sampel sebanyak 30 petani.

\section{Metode Analisis Data}

\section{Biaya}

Biaya produksi yang dikeluarkan petani kentang pada satu musim tanam diantaranya biaya tetap (sewa tanah maupun pajak lahan) dan biaya variabel (biaya benih, biaya pestisida, dan biaya tenaga kerja). Kedua biaya tersebut dijumlahkan dan disebut sebagai biaya usahatani kentang. Menurut Soekartawi (1993) biaya total dirumuskan sebagai berikut

$$
\mathbf{T C}=\mathbf{F C}+\mathrm{VC}
$$

Keterangan :

$$
\begin{aligned}
& \mathrm{TC}=\text { Total Cost }(\text { Biaya Total }) \\
& \mathrm{FC}=\text { Fixed Cost }(\text { Biaya Tetap }) \\
& \mathrm{VC}=\text { Variable Cost }(\text { Biaya Variabel })
\end{aligned}
$$




\section{Pendapatan}

Hubungan antara biaya, pendapatan menurut Soekartawi (1993) dapat dinyatakan dalam rumus sebagai berikut :

$$
\begin{aligned}
& \text { Pd }=\text { TR }- \text { TC } \\
& \text { Pd }=\text { TR }-(\text { FC }+ \text { VC }) \\
& \text { Pd }=(\text { Y.Py })-(\text { FC }+ \text { VC })
\end{aligned}
$$

Keterangan :

Pd = Pendapatan Usahatani

$\mathrm{TR}=$ Total Penerimaan

$\mathrm{TC}=$ Total Biaya

$\mathrm{FC}=$ Biaya Tetap

$\mathrm{VC}=$ Biaya Variabel

$\mathrm{Y}=$ Produksi yang diperoleh dalam usahatani

Py = Harga satuan Y

\section{Analisis Kelayakan}

Nilai R/C merupakan perbandingan antara penerimaan total atau total revenue (TR) dengan biaya total atau total cost (TC). Menurut Rahardi (1995) R/C merupakan suatu perbandingan antara output dengan input yang diarahkan pada suatu usaha untuk membandingkan, mengukur serta mempertimbangkan tingkat keuntungan usaha,

\section{$\mathrm{R} / \mathrm{C}=\mathrm{TR} / \mathrm{TC}$}

Keterangan :

$\mathrm{TR}=$ Penerimaan Total atau Total Revenue (TR)

TC = Biaya Total atau Total Cost (TC)

Jika ditemukan :

$\mathrm{R} / \mathrm{C}>1$ maka usaha tersebut menguntungkan karena menunjukkan penerimaan yang diperoleh lebih besar dari biaya yang dikeluarkan
$\mathrm{R} / \mathrm{C}=1$ maka usaha tersebut hanya cukup untuk menutup biaya atau tidak untung maupun rugi

$\mathrm{R} / \mathrm{C}<1$ maka usaha tersebut tidak menguntungkan sebaiknya usaha tersebut tidak dilaksanakan

\section{Analisis Risiko}

Analisis risiko berhubungan dengan teori pengambilan keputusan (decision theory). Individu diasumsikan untuk bertindak rasional dalam mengambil keputusan bisnis. Alat analisis yang umumnya digunakan dalam menganalisis mengenai pengambilan keputusan yang berhubungan dengan risiko yaitu analisis produksi, analisis harga dan analisis pendapatan.

\section{Analisis Risiko Produksi}

Untuk mengetahui risiko produksi usahatani kentang dapat dihitung berdasar rumus Hernanto (1993) yaitu :

$$
C V a=\frac{V a}{E a}
$$

Keterangan :

$\mathrm{CVa}=$ koefisien variasi risiko produksi

$\mathrm{Va}=$ Simpangan baku produksi usahatani kentang $(\mathrm{kg})$

Ea $=$ Produksi rata-rata usahatani kentang $(\mathrm{kg})$

Sebelum mengukur koefisien variasi risiko produksi terlebih dahulu harus mencari ratarata produksi petani kentang dan simpangan bakunya. Secara statistic risiko dapat dihitung dengan menggunakan ukuran keragaman (variance) maupun simpangan baku (Standard Deviation). Keragaman secara matematis dirumuskan sebagai berikut : 


$$
V a^{2}=\frac{\sum_{i=1}^{n}(E i a-E a)^{2}}{n-1}
$$

Keterangan :

$\mathrm{Va}^{2}=$ Keragaman Produksi

$\Sigma=$ Simbol operasi penjumlahan

Eia $=$ Produksi yang diterima petani $(\mathrm{kg})$

$\mathrm{Ea}=$ Produksi rata-rata petani $(\mathrm{kg})$

$\mathrm{n} \quad=$ Jumlah responden dalam penelitian

Adapun rumus simpangan baku yaitu :

$$
V a=\sqrt{v a^{2}}
$$

Keterangan :

$\mathrm{Va}=$ Simpangan baku produksi $(\mathrm{kg})$

$\mathrm{Va}^{2}=$ Keragaman Produksi $(\mathrm{kg})$

Batas bawah produksi menunjukkan nilai produksi terendah yang mungkin diterima oleh petani. Apabila nilai batas bawah produksi ini sama dengan nol maka petani tidak akan pernah mengalami kerugian. Sebaliknya jika nilai batas bawah produksi kurang dari nol dapat disimpulkan bahwa dalam setiap proses produksi ada peluang keruugian yang akan diderita oleh petani. Adapun rumus batas bawah produksi adalah :

$$
\mathbf{L a}=\mathbf{E a}-2 \mathrm{Va}
$$

\section{Keterangan}

$\mathrm{La}=$ Batas bawah produksi $(\mathrm{kg})$

$\mathrm{Ea}=$ Produksi rata-rata yang diperoleh $(\mathrm{kg})$

$\mathrm{Va}=$ Simpangan baku produksi $(\mathrm{kw})$

Apabila $\mathrm{CV}>0,5$ maka nilai $\mathrm{L}<0$, Begitu pula jika nilai $\mathrm{CV} \leq 0,5$ dan nilai $\mathrm{L} \geq 0$. Hal ini menunjukan bahwa apabila $\mathrm{CV}>0,5$ maka resiko produksi usahatani kentang semakin besar dengan menanggung kerugian sebesar L, sedangkan nilai $\mathrm{CV} \leq 0,5$ maka petani akan selalu untung atau impas dengan produksi sebesar L.

\section{Analisis Risiko Harga}

Untuk mengetahui risiko harga usahatani kentang dapat dihitung berdasar rumus Hernanto (1993) yaitu :

$$
\boldsymbol{C V} \boldsymbol{b}=\frac{V \boldsymbol{b}}{E \boldsymbol{b}}
$$

Keterangan :

$\mathrm{CVb}=$ koefisien variasi risiko harga

$\mathrm{Vb} \quad=$ Simpangan baku harga kentang $(\mathrm{kg})$

$\mathrm{Eb} \quad=$ Harga rata-rata kentang $(\mathrm{kg})$

Sebelum mengukur koefisien variasi risiko harga terlebih dahulu harus mencari harga ratarata kentang dan simpangan bakunya. Secara statistic risiko dapat dihitung dengan menggunakan ukuran keragaman (variance) maupun simpangan baku (Standard Deviation). Keragaman secara matematis dirumuskan sebagai berikut :

$$
V b^{2}=\frac{\sum_{i=1}^{n}(E i b-E b)^{2}}{n-1}
$$

Keterangan :

$\mathrm{Vb}^{2}=$ Keragaman Harga

$\Sigma=$ Simbol operasi penjumlahan

Eib $=$ Harga yang diterima petani (rupiah)

$\mathrm{Eb}=$ Harga rata-rata petani (rupiah)

$\mathrm{n}=$ Jumlah responden dalam penelitian

Adapun rumus simpangan baku yaitu :

$$
V b=\sqrt{v b^{2}}
$$

Keterangan :

$\mathrm{Vb}=$ Simpangan baku harga (rupiah)

$\mathrm{Vb}^{2}=$ Keragaman harga (rupiah)

Batas bawah harga menunjukkan hargaterendah yang mungkin diterima oleh petani. Apabila nilai batas bawah harga ini sama dengan nol maka petani tidak akan pernah mengalami kerugian. Sebaliknya jika 
nilai batas bawah harga kurang dari nol dapat disimpulkan bahwa dalam setiap proses pembentukan harga ada peluang keruugian yang akan diderita oleh petani. Adapun rumus batas bawah harga adalah :

$$
\mathbf{L b}=\mathbf{E b}-\mathbf{2 V b}
$$

\section{Keterangan}

$\mathrm{Lb}=$ Batas bawah harga (rupiah)

$\mathrm{Eb}$ = harga rata-rata yang diperoleh (rupiah)

$\mathrm{Vb}=$ Simpangan baku harga (rupiah)

Apabila CV $>0,5$ maka nilai $\mathrm{L}<0$, Begitu pula jika nilai $\mathrm{CV} \leq 0,5$ dan nilai $\mathrm{L} \geq 0$. Hal ini menunjukan bahwa apabila $\mathrm{CV}>0,5$ maka resiko harga usahatani kentang semakin besar dengan menanggung kerugian sebesar L, sedangkan nilai $\mathrm{CV} \leq 0,5$ maka petani akan selalu untung atau impas dengan harga sebesar L.

\section{Analisis Risiko Pendapatan}

Untuk mengetahui risiko pendapatan usahatani kentang dapat dihitung berdasar rumus Hernanto (1993) yaitu :

$$
C V c=\frac{V c}{E c}
$$

Keterangan :

$\mathrm{CV} \mathrm{c}=$ koefisien variasi risiko pendapatan

$\mathrm{Vc}=$ Simpangan baku pendapatan petani kentang (rupiah)

Ec = Pendapatan rata-rata petani kentang (rupiah)

Sebelum mengukur koefisien variasi risiko pendapatan terlebih dahulu harus mencari pendapatan rata-rata petani kentang dan simpangan bakunya. Secara statistic risiko dapat dihitung dengan menggunakan ukuran keragaman (variance) maupun simpangan baku (Standard Deviation). Keragaman secara matematis dirumuskan sebagai berikut :

$$
=\frac{\sum_{i=1}^{n}(E i c-E c)^{2}}{n-1}
$$

Keterangan :

$\mathrm{Vc}^{2}=$ Keragaman Pendapatan

$\sum=$ Simbol operasi penjumlahan

Eic $=$ Pendapatan yang diterima petani (rupiah)

Ec = Pendapatan rata-rata petani (rupiah)

$\mathrm{n} \quad=$ Jumlah responden dalam penelitian

Adapun rumus simpangan baku yaitu :

$$
V c=\sqrt{v c^{2}}
$$

Keterangan :

$\mathrm{Vc}$ = Simpangan baku pendapatan (rupiah)

$\mathrm{Vc}^{2}=$ Keragaman pendapatan (rupiah)

Batas bawah pendapatan menunjukkan pendapatan terendah yang mungkin diterima oleh petani. Apabila nilai batas bawah pendapatan ini sama dengan nol maka petani tidak akan pernah mengalami kerugian. Sebaliknya jika nilai batas bawah pendapatan kurang dari nol dapat disimpulkan bahwa dalam setiap proses perolehan pendapatanada peluang keruugian yang akan diderita oleh petani. Adapun rumus batas bawah harga adalah :

$$
\text { Lc }=\mathrm{Ec}-2 \mathrm{Vc}
$$

Keterangan

$\mathrm{Lc}=$ Batas bawah pendapatan (rupiah)

$\mathrm{Ec}=$ Pendapatan rata-rata yang diperoleh (rupiah)

$\mathrm{Vc}=$ Simpangan baku pendapatan (rupiah)

Apabila $\mathrm{CV}>0,5$ maka nilai $\mathrm{L}<0$, Begitu pula jika nilai $C V \leq 0,5$ dan nilai $L \geq 0$. Hal ini menunjukan bahwa apabila $\mathrm{CV}>0,5$ maka 
resiko pendapatan usahatani kentang semakin besar dengan menanggung kerugian sebesar L, sedangkan nilai $\mathrm{CV} \leq 0,5$ maka petani akan selalu untung atau impas dengan pendapatan sebesar L.

\section{HASIL DAN PEMBAHASAN}

\section{Kelayakan Usahatani Kentang Desa Kutawaba Kecamatan Karangreja Kabupaten Purbalingga Biaya Usahatani}

Biaya usahatani meliputi biaya tetap dan biaya variabel. Biaya tetap meliputi biaya pajak lahan dan juga biaya penyusutan pada alat-alat pertanian yang digunakan seperti cangkul, pompa air, selang, dll. Sedangkan biaya variabel terdiri dari biaya pengadaan benih, pupuk organik, pupuk kimia, pestisida, dan juga tenaga kerja. Rincian biaya yang dikeluarkan petani kentang dengan luas lahan rata-rata 0,46 Ha dapat dilihat pada Tabel 1.

Berdasarkan Tabel 1, diketahui bahwa hampir sebagian besar biaya tetap didominasi oleh biaya penyusutan alat-alat pertanian $(11,05 \%)$ sedangkan sisanya dikeluarkan untuk pajak lahan $(0,1 \%)$.

Tabel 1. Rata-Rata Biaya Usahatani Kentang di Desa Kutawaba Kecamatan Karangreja Kabupaten Purbalingga $(0,46 \mathrm{Ha})$

\begin{tabular}{|c|c|c|c|}
\hline No & Uraian Biaya yang dikeluarkan & Rata-Rata (Rp) & Presentase $(\%)$ \\
\hline 1. & Biaya Tetap & 2.427.634 & 11,16 \\
\hline & & 23.000 & 0,1 \\
\hline \multicolumn{2}{|r|}{ b. Penyusutan Alat } & 2.404 .634 & 11,05 \\
\hline & Cangkul & 15.996 & 0,07 \\
\hline & Diesel & 51.578 & 0,24 \\
\hline & 3) Selang & 644.444 & 2,96 \\
\hline & 4) Tangki Sprayer & 234.306 & 1,07 \\
\hline & 5) Mulsa & 1.190 .000 & 5,47 \\
\hline & 6) Bambu & 244.66 & 1,13 \\
\hline & Tali & 23.644 & 0,1 \\
\hline \multicolumn{2}{|r|}{ Biaya Variabel } & 19.346.521 & $\mathbf{8 8 , 9 7}$ \\
\hline & & 9.168 .989 & 42,16 \\
\hline \multicolumn{2}{|r|}{$\begin{array}{l}\text { a. Bibit } \\
\text { b. Pupuk Organik }\end{array}$} & 3.661 .460 & 16,84 \\
\hline \multicolumn{2}{|r|}{ c. Pupuk Kimia } & 3.731 .750 & 17,16 \\
\hline \multicolumn{2}{|r|}{ d. Pestisida } & 587.708 & 2,7 \\
\hline \multicolumn{2}{|r|}{ e. Tenaga Kerja } & 2.196 .613 & 10,1 \\
\hline & Total Biaya & 21.744 .673 & 100 \\
\hline
\end{tabular}

Sumber : Analisis Data Primer, 2020

Biaya penyusutan alat terbesar adalah digunakan untuk mulsa sebesar Rp 1.190.0000 $(5,47 \%)$. Mulsa dapat digunakan dalam 3 kali musim tanam atau setahun dengan harga 1 roll mulsa sekitar Rp 700.000. Hal ini yang menyebabkan biaya untuk mulsa menjadi tinggi. Adapun biaya terbesar kedua yaitu biaya penyusutan selang dimana selang digunakan petani untuk mengalirkan air melalui mesin diesel ke lahan dengan harga per satuannya Rp 1.800.000 hingga Rp 2.000.000. Sisa biaya lainnya yaitu penyusutan pada bamboo, tangka sprayer, diesel, tali, dan cangkul. 
Adapun biaya variabel tertinggi diperuntukkan untuk pengadaan bibit yaitu $\mathrm{Rp}$ 9.168.988,89 atau sebesar 42,16\% dari total biaya. Sebanyak $56,67 \%$ responden petani mengadakan bibit secara mandiri sehingga biaya bibit Rp 0 dan 43,33\% responden lainnya membeli bibit dari luar daerah dengan harga Rp 20.000 hingga Rp 35.000 dan dengan jumlah penggunaan disesuaikan dengan luas lahan dari 200 hingga 2000 bibit. Biaya variabel berikutnya yaitu pupuk kimia $(19,23 \%)$, pupuk organic $(18,92 \%)$, tenaga kerja $(11,35 \%)$, dan pestisida (3,03\%).

\section{Penerimaan dan Pendapatan}

Penerimaan usahatani kentang Desa Kutaabwa sendiri diperoleh dengan mengalikan rata-rata hasil produksi kentang dengan rata-rata harga jual. Sedangkan pendapatan merupakan pengurangan dari penerimaan yang diperoleh dengan total biaya produksi yang dikeluarkan selama proses produksi. Hasil penerimaan dan pendapatan usahatani kentang Desa Kutabawa dapat dilihat pada tabel 2.

Tabel 2. Rata-Rata Penerimaan dan Pendapatan usahatani kentang di Desa Kutawaba Kecamatan Karangreja Kabupaten

\begin{tabular}{ccc}
\multicolumn{3}{c}{ Purbalingga $(0,46 \mathrm{Ha})$} \\
\hline No & Uraian & $\begin{array}{c}\text { Rata-Rata } \\
(\mathbf{R p})\end{array}$ \\
\hline 1 & Penerimaan (Rp) & $\mathbf{5 0 . 6 3 3 . 3 3 3}$ \\
2 & Jumlah Produksi (Kg) & 7.000 \\
3 & Harga Kentang (Rp) & 7.233 \\
4 & Total Biaya (Rp) & $\mathbf{2 1 . 7 4 4 . 6 7 3}$ \\
5 & Pendapatan (Rp) & $\mathbf{2 8 . 8 8 8 . 6 6 1}$ \\
\hline \multicolumn{3}{c}{ Sumber : Analisis Data Primer, 2020 }
\end{tabular}

Menurut tabel 2 diketahui bahwa rata-rata penerimaan petani kentang Desa Kutawaba per musim tanam dengan luas rata-rata 0,46 ha yaitu sebesar Rp 50.633.333. Rata-rata produksi petani mencapai 7 ton dengan harga jual sekitar Rp 7.233. Dari perhitungan tersebut ditemukan pendapatan sebesar $\mathrm{Rp}$ 28.888.661 yang diperoleh dari penerimaan sebesar Rp 50.633.333 dikurangi dengan total biaya $\operatorname{Rp} 21.744 .673$.

\section{Kelayakan Usahatani}

Usahatani kentang di Desa Kutabawa pada 1 musim tanam dengan rata-rata luas lahan sebesar 0,46 Ha memperoleh penerimaan (R) sebesar Rp 50.633.333, sedangka biaya yang dikeluarkan (C) sebesar Rp 21.744.673. Berdasarkan perhitungan tersebut maka diperoleh R/C sebesar 2,33 (R/C > 1) yang menunjukkan bahwa Usahatani Kentang di Desa Kutabawa Kecamatan Karangreja Kabupaten Purbalingga layak untuk diusahakan.

\section{Analisis Risiko}

\section{Risiko Produksi}

Risiko produksi sangat berpengaruh terhadap perilaku petani dalam mengambil keputusan khususnya pada saat membudidayakan kentang. Adapun besarnya risiko produksi usahatani kentang di Desa Kutabawa Kecamatan Karangreja Kabupaten Purbalingga dapat dilihat pada Tabel 3.

Tabel 3 menunjukkan bahwa petani kentang di Desa Kutabawa memiliki rata-rata produksi sebesar $7000 \mathrm{~kg}$ per sekali musim tanam. 
Tabel 3. Risiko Produksi Usahatani Kentang di Desa Kutabawa Kecamatan Karangreja Kabupaten Purbalingga

\begin{tabular}{clc}
\hline No. & \multicolumn{1}{c}{ Uraian } & $\begin{array}{c}\text { Per } \\
\text { Musim } \\
\text { Tanam }\end{array}$ \\
\hline 1 & Rata-Rata Produksi (Kg) & 7000 \\
2 & Simpangan Baku (STDV) & 5561.5 \\
3 & Koefisien Variasi (Cva) & 0.7945 \\
4 & Batas Bawah Produksi (La) & -4123 \\
\hline \multicolumn{2}{c}{ Sumber : Analisis Data Primer, 2020 }
\end{tabular}

Melalui perhitungan produksi tersebut maka dapat diketahui besarnya simpangan baku usahatani kentang di Desa Kutawaba sebesar 5561,1 kg. Dari membandingkan antara simpangan baku dengan rata-rata produksi maka ditemukan koefisien variasi sebesar 0,7945 dengan batas bawah produksi sebesar $-4123 \mathrm{~kg}$.

Berdasarkan perhitungan koefisien variasi dan batas bawah maka dapat diketahui bahwa produksi kentang yang dilakukan petani di Desa Kutabawa tergolong berisiko. Hal ini dikarenakan nilai koefisien variasi yang lebih dari $0,5(0,7945>0,5)$ dan juga batas bawah produksi sebesar $-4123 \mathrm{~kg}$ dimana kurang dari 0 dimana menurut teori yang dikemukakan oleh Hernanto (1991) maka usahatani tergolong beresiko. Berdasarkan perhitungan koefisien variasi sebesar 0,7945 disimpulkan bahwa risiko produksi kentang semakin besar dengan menanggung kerugian sebesar -4123 $\mathrm{kg}$.

\section{Risiko Harga}

Harga dari suatu komoditi merupakan suatu hal yang penting karena merupakan salah satu faktor penentu dari penerimaan (Revenue). Sehingga perlu diketahui fluktuasinya yang nanti akan mencerminkan tingkat risiko khususnya dari komoditas kentang ini. Adapun risiko harga usahatani kentang di Desa Kutabawa dapat dilihat pada Tabel 4.

Tabel 4. Risiko Harga Usahatani Tomat di Desa Kutabawa Kecamatan Karangreja Kabupaten Purbalingga.

\begin{tabular}{clc}
\hline No. & \multicolumn{1}{c}{ Uraian } & $\begin{array}{c}\text { Per } \\
\text { Musim } \\
\text { Tanam }\end{array}$ \\
\hline 1 & Rata-Rata Harga (Rp) & 7233.33 \\
2 & Simpangan Baku (STDV) & 1489.81 \\
3 & Koefisien Variasi (Cva) & 0.205965 \\
4 & Batas Bawah Produksi (La) & 4253.71 \\
\hline \multicolumn{2}{c}{ Sumber : Analisis Data Primer, 2020 }
\end{tabular}

Tabel 4 menunjukkan bahwa harga rata-rata dari $1 \mathrm{~kg}$ kentang di Desa Kutabawa adalah sebesar Rp 7.233,33. Berdasarkan perhitungan diketahui pula bahwa simpangan baku pada harga kentang di Desa Kutawaba sebesar Rp 1.489,81. Dari membandingkan antara simpangan baku dengan rata-rata produksi maka ditemukan koefisien variasi sebesar 0,206965 dengan batas bawah produksi sebesar Rp 4253,71.

Berdasarkan perhitungan koefisien variasi dan batas bawah maka dapat diketahui bahwa harga kentang yang diperoleh petani di Desa Kutabawa tidak berisiko pada satu musim saat penelitian. Hal ini dikarenakan nilai koefisien variasi yang kurang dari $0,5(0,206965<0,5)$ dan juga batas bawah produksi sebesar Rp 4253,71 dimana kurang dari 0 dimana menurut teori yang dikemukakan oleh Hernanto (1991) maka usahatani akan selalu untung atau impas dengan kenaikan harga sebesar Rp 4253,71.

\section{Risiko Pendapatan}

Pendapatan usahatani merupakan faktor utama dari sebuah usahatani termasuk 
usahatani kentang di Desa Kutabawa. Oleh karenanya perlu diketahui tingkat risiko yang ada sehingga petani dapat mengantisipasinya sebelumnya. Adapun risiko pendapatan usahatani kentang di Desa Kutabawa dapat dilihat pada Tabel 5.

Tabel 5. Risiko Pendapatan Usahatani Tomat di Desa Kutabawa Kecamatan Karangreja Kabupaten Purbalingga.

\begin{tabular}{clc}
\hline No. & \multicolumn{1}{c}{ Uraian } & $\begin{array}{c}\text { Per Musim } \\
\text { Tanam }\end{array}$ \\
\hline 1 & Rata-Rata Pendapatan (Rp) & 28.888 .661 \\
2 & Simpangan Baku (STDV) & 29.147 .265 \\
3 & Koefisien Variasi (Cva) & 1,00895177 \\
4 & Batas Bawah Produksi (La) & -29.405 .870 \\
\hline \multicolumn{3}{c}{ Sumber : Analisis Data Primer, 2020 }
\end{tabular}

Tabel 5 menunjukkan bahwa pendapatan dari usahatani kentang di Desa Kutabawa dengan rata-rata luas lahan sebesar 0,46 ha adalah sebesar Rp. 28.888.661. Berdasarkan perhitungan diketahui pula bahwa simpangan baku pada harga kentang di Desa Kutawaba sebesar Rp 29.147.265. Dari membandingkan antara simpangan baku dengan rata-rata pendapatan maka ditemukan koefisien variasi 1,00895177 dengan batas bawah pendapatan sebesar - Rp 29.405.870.

Berdasarkan perhitungan koefisien variasi dan batas bawah maka dapat diketahui bahwa pendapatan usahatani kentang yang diperoleh petani di Desa Kutabawa tergolong berisiko. Hal ini dikarenakan nilai koefisien variasi yang lebih dari 0,5 (1,00895177>0,5) dan juga batas bawah pendapatan sebesar - Rp 29.405.870 dimana kurang dari 0 dimana menurut teori yang dikemukakan oleh Hernanto (1991) maka pendapatan usahatani tergolong beresiko. Berdasarkan perhitungan koefisien variasi sebesar 1,00895177 disimpulkan bahwa risiko pendapatan kentang semakin besar dengan menanggung kerugian sebesar - Rp 29.405.870.

\section{KESIMPULAN DAN SARAN}

\section{Kesimpulan}

Rata-rata biaya yang dikeluarkan oleh petani kentang di Desa Kutabawa Kecamatan Karangreja Kabupaten Purbalingga dengan rata-rata luas lahan 0,46 Ha adalah sebesar Rp 21.744.673 dengan rincian biaya tetap sebesar Rp 2.427.634,456 dan biaya variabel sebesar Rp 19.346.521. Sedangkan penerimaan yang diperoleh dari usahatani kentang sebesar Rp 50.633 .333 dengan rata-rata jumlah produksi $7.000 \mathrm{~kg}$ dan dengan harga jual Rp 7.233 sehingga diperoleh pendapatan sebesar $\mathrm{Rp}$ 28.888.661. Adapun dilihat dari tingkat kelayakannya diperoleh R/C Ratio sebesar 2,33 atau > 1 yang menunjukkan bahwa Usahatani Kentang di Desa Kutabawa Kecamatan Karangreja Kabupaten Purbalingga layak untuk diusahakan.

Usahatani Kentang di Desa Kutabawa Kecamatan Karangreja Kabupaten Purbalingga jika ditinjau dari aspek produksi dan pendapatan memiliki risiko tinggi karena memiliki koefisien variasi yang lebih dari 0,5 $(0,7945$ untuk produksi dan 1,00895177 untuk pendapatan) dan juga batas bawah produksi sebesar $-4123 \mathrm{~kg}$ dan batas bawah pendapatan sebesar - Rp 29.405.870 dimana kurang dari 0. Sedangkan dilihat dari aspek harga memiliki koefisien variasi yang kurang dari 0,5 $(0,206965<0,5)$ dan juga batas bawah 
produksi sebesar Rp 4253,71 dimana usahatani akan selalu untung atau impas dengan kenaikan harga sebesar Rp 4253,71.

\section{Saran}

Petani kentang di Desa Kutabawa Kecamatan Karangreja Kabupaten Purbalingga harus merencanakan kegiatan usahataninya dengan lebih cermat khususnya pada aspek produksi dan juga prediksi panen. Sehingga mampu meminimalisir risiko yang ada.

Petani dapat bekerjasama antar petani dan juga lembaga permodalan untuk pengadaan alat pertanian dan juga faktor produksi lainnya secara kolektif sehingga dapat menekan biaya produksi dalam rangka memperoleh pendapatan yang lebih tinggi.

\section{DAFTAR PUSTAKA}

Arikunto, Suharsimi. 1998. Prosedur Penelitian Suatu Pendekatan Praktek. Rineka Cipta, Jakarta.

Badan Pusat statistik Kabupaten Purbalingga. 2016. Kabupaten Purbalingga dalam angka 2018. Purbalingga.

Badan Pusat statistik Kabupaten Purbalingga. 2018. Kabupaten Purbalingga dalam angka 2018. Purbalingga.

Badan Pusat Statistik. 2018. Luas Panen dan Produksi Tanaman Sayuran dan Buahbuahan Semusim Menurut Kabupaten/Kota di Jawa Tengah, 2016 2016. Jawa Tengah.

Hernanto F. 1993. Ilmu Usahatani. Jakarta : PT. PEnebar Swadaya.

Kuntjoro, A. S. 2000. Produksi Umbi Mini Kentang G0 Bebas Virus melalui Perbanyakan Planlet secara Kultur Jaringan di PT. Intidaya Agrolestari (Inagro) Bogor - Jawa Barat. Disertasi. Institus Pertanian Bogor.

Rahardi, F, 1995. Agribisnis Tanaman Perkebunan. Penebar Swadaya, Jakarta.
Safitri, Inandia. 2015. Studi Komparasi Usahatani Sayuran di Desa Kutabawa dan Desa Siwarak Kecamatan Karangreja Kabupaten Purbalingga. Jurnal.

Soekartawi,1993. Analisis Usahatani.UI Pres.Jakarta

Sugiyono. 2008. Metode Penelitian Kuantitatif Kualitatif dan R\&D. Bandung : ALFABETA 